\title{
Cloning and Characterization of $\chi-1$ : A Developmentally Regulated Member of a Novel Class of the lonotropic Glutamate Receptor Family
}

\author{
Anthony M. Ciabarra, ${ }^{1,2}$ Jane M. Sullivan, ${ }^{3}$ Laura G. Gahn, ${ }^{2}$ Gerlinde Pecht, ${ }^{3,4}$ Stephen Heinemann, ${ }^{3}$ and Kevin \\ A. Sevarino 2 \\ Division of Molecular Psychiatry, Departments of ${ }^{1}$ Pharmacology and ${ }^{2} P$ sychiatry, Yale University School of \\ Medicine and Connecticut Mental Health Center, New Haven, Connecticut 06508, ${ }^{3}$ Molecular Neurobiology \\ Laboratory, The Salk Institute, La Jolla, California 92037, and ${ }^{4}$ xsys, Inc., San Diego, California 92121
}

lonotropic glutamate receptors are composed of homomeric or heteromeric configurations of glutamate receptor subunits. We have cloned a member of a novel class of the rat ionotropic glutamate receptor family, termed $x-1$. This subunit exhibits an average identity of $27 \%$ to NMDA subunits and $23 \%$ to non-NMDA subunits. Regional transcript levels of $x^{-1}$ are elevated just prior to and during the first postnatal week, with the highest levels present in the spinal cord, brainstem, hypothalamus, thalamus, CA1 field of the hippocampus, and amygdala. The spatial distribution of $\chi-1$ expression is similar from postnatal day 1 (P1) to adulthood. However, transcript levels decline sharply between P7 and P14 and remain attenuated into adulthood. Functlonal expression studles in Xenopus oocytes Injected with in vitro transcribed $x-1$ RNA did not demonstrate agonist-activated currents. Pairwise expression of $\chi^{-1}$ with members of the AMPA, KA, or $\delta$ class of glutamate receptor subunits either failed to generate agonist-activated currents or failed to alter the underlying current generated by the coexpressed subunit. However, coexpression of $x-1$ with subunits forming otherwise functional NMDA receptors resulted in an inhibition of current responses. Since $x-1$ did not alter the currents generated by non-NMDA subunits, this suggests that $\chi-1$ may specifically interact with NMDA receptor subunits. Further characterization will be required to establish the precise role of this glutamate receptor subunit in neuronal signaling.

[Key words: glutamate, receptor, cloning, NMDA, ionotropic, subunit]

\footnotetext{
Received Dec. 29, 1994; revised Apr. 28, 1995; accepted May 3, 1995

Special thanks to Dr. Jim Boulter for the use of the NMDAR2D, KA-1, and delta-1 clones, Dr. Emily Liman for allowing us to use the pGEMHE vector, and Chris Boyer for oocyte preparation. We also acknowledge Dr. John Marshall for advice on transfections, and Drs. John Alvaro, Mustafa Sahin, Ariel Deutch, and Susan Hockfield for assistance with the developmental studies. We would also like to thank Drs. Eric Nestler and Ron Duman for helpful discussions. These studies were partially supported by grants from the Scottish Rite Schizophrenia Research Program and U.S. Public Health Services Grant RR05358 (K.A.S.) and the Abraham Ribicoff Research Facilities of the Connecticut Mental Health Center, State of Connecticut Department of Mental Health (A.M.C., L.G.G., K.A.S). This work was also supported by NINCDS Grant NS28709 to S.H. and The McKnight Foundation (S.H.).

Correspondenec should be addressed to Kevin A. Sevarino, Division of Molecular Psychiatry, Department of Psychiatry, Yale University School of Medicine and Connecticut Mental Health Center, 34 Park Street, New Haven, CT 06508 .

Copyright (C) 1995 Society for Neuroscience 0270-6474/95/156498-11\$05.00/0
}

The majority of rapid excitatory transmission in the nervous system is mediated by glutamate-activated ion channels. Ionotropic glutamate receptors have been subdivided pharmacologically into AMPA ( $\alpha$-amino-3-hydroxy-5-methyl-4-isoxazole propionic acid), KA (kainate), and NMDA subtypes (Monaghan et al., 1989). These receptors have been implicated in a number of physiological and pathological processes. During development, glutamate receptors are involved in neuronal differentiation, migration, and activity-dependent synapse formation (Balazs et al., 1989; Brewer, 1989; Komoru and Rakic, 1993). In mature neurons, long-term potentiation and long-term depression require ionotropic glutamate receptors (Collingridge and Lester, 1989; McDonald and Johnston, 1990; Bliss and Collingridge, 1993; Malenka, 1994). Glutamate-gated ion channels also play a central role in mediating the excitotoxic effects of glutamate (Olney, 1990). Pathophysiological processes thought to involve glutamate excitotoxicity and neurodegeneration include epilepsy, stroke, Parkinson's disease, Alzheimer's disease, Huntington's disease, and amyotrophic lateral sclerosis (Choi, 1988; Monaghan et al., 1989).

Molecular cloning efforts have identified 16 rat ionotropic glutamate receptor subunits (see Seeburg, 1993; Hollman and Heinemann, 1994). These subunits are divided into six classes, including the AMPA subunits, the high and low affinity KA subunits, the NMDAR1 and NMDAR2 subunits, and the pharmacologically undefined $\delta$ class. These subunits are thought to form oligomeric glycoprotein complexes whose precise stoichiometry is unknown (Blackstone et al., 1992; Wenthold et al., 1992; Brose et al., 1993; Chazot et al., 1994).

Functional homomeric NMDA receptors can be formed from the NMDAR1 subunit (Moriyoshi et al., 1991; Nakanishi et al., 1992; Yamazaki et al., 1992). However, coexpression of NMDAR1 with a member of the NMDAR2A-D class greatly enhances the agonist-gated currents. Each NMDAR2 subunit confers unique properties to the resulting heteromeric NMDA receptor (Ikeda et al., 1992; Kutsuwada et al., 1992; Meguro et al., 1992; Monyer et al., 1992; Ishii et al., 1993).

Discrepancies between the properties of heteromeric NMDA receptors formed from cloned subunits and in vivo NMDA receptors have suggested that some native NMDA receptors may contain additional uncharacterized subunits. Photoaffinity ligand studies on heteromeric receptors expressed in HEK-293 cells do not adequately describe the patterns of labeling seen in vivo (Marti et al., 1993). In addition, glycine affinities for expressed heteromeric NMDA receptors are 10 -fold lower than those ob- 
A

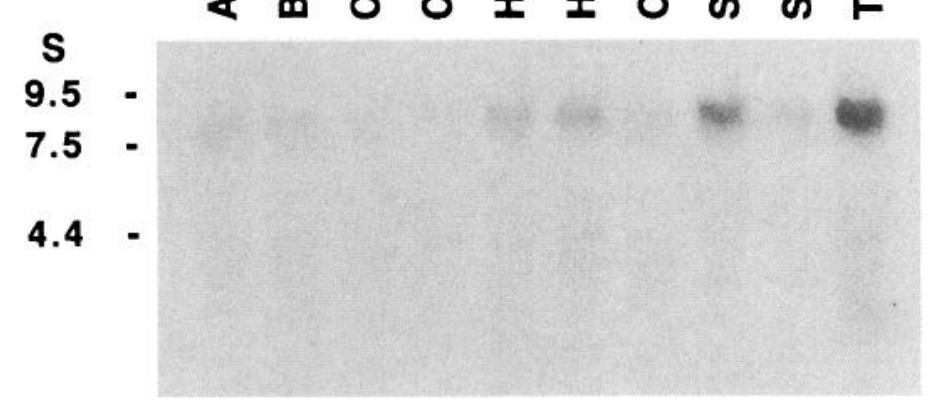

B

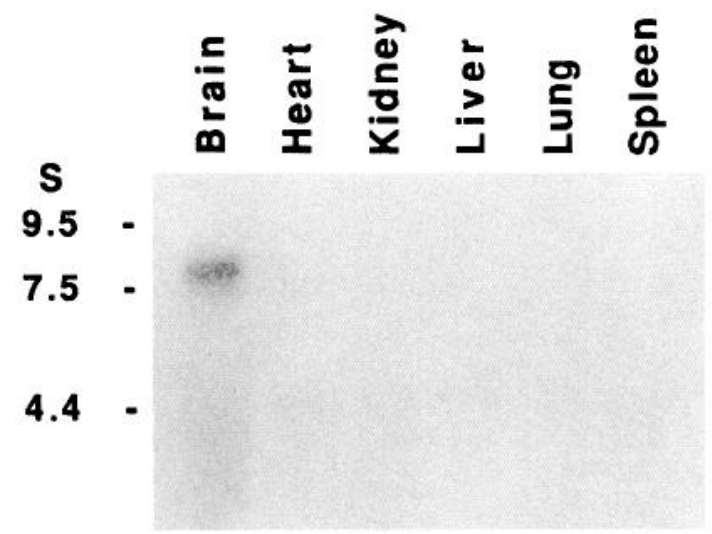

Figure 1. Northern blot analysis of $\chi^{-1}$ transcript expression in brain regions $(A)$ and peripheral tissues $(B)$ of the adult rat. Fifteen micrograms of total RNA were run on a $1 \%$ agarose-formaldehyde gel, transferred to a nylon membrane, and probed with a 342 bp ${ }^{32} \mathrm{P}-1$ labeled fragment of the $\chi-1$ subunit. The blot was exposed to film for $4 \mathrm{~d}$ with a screen. $S$, RNA molecular weight standards in kilobases.

served in vivo, with the exception of NMDAR $1 / 2 \mathrm{C}$ receptors (Laurie and Seeburg, 1994).

We have identified a putative member of a new class of the ionotropic glutamate receptor family, termed $\chi-1$. In the following study, we present the sequence of $\chi-1$, examine its structural features and expression properties, and characterize its mRNA distribution within the developing and adult rat brain.

\section{Materials and Methods}

Degenerate polymerase chain reaction. Two degenerate primers, G1 [5'TGGAA(C,T)GG(C,A,G)ATG(A,G)T(G,A,T)GGNGA-3'] which spans the residues WNGMVGEL upstream of transmembrane region I (TM I), and G2 [5'-AA(A,G)GC(A,T,G)GCCA(A,G)(A,G)TT(A,T,G)GCIG$\left.\mathrm{T}(\mathrm{A}, \mathrm{G}) \mathrm{T}-3^{\prime}\right]$ which spans the residues YTANLAAF in TM III, were designed based on the sequences of GluR1-7, KA-1, KA-2, and NMDAR1. These primers were similar to those used by Monyer et al. (1992). Rat brain mRNA was prepared from total RNA using the PolyATtract system (Promega) and subsequently converted to cDNA using Superscript $\mathrm{RNaseH}^{-}$reverse transcriptase (GIBCO-BRL) as directed by the manufacturer. PCR reactions were performed in $50 \mu \mathrm{l}$ reactions containing $10 \mathrm{mM}$ Tris- $\mathrm{HCl}, \mathrm{pH} 8.3,50 \mathrm{mM} \mathrm{KCl}, 1.5 \mathrm{~mm}$ $\mathrm{MgCl}_{2}, 0.01 \%$ gelatin, $0.2 \mathrm{~mm}$ each of dATP, dGTP, dCTP, and dTTP, 80 pmol of each primer, $5 \mathrm{ng}$ of rat brain cDNA, and $1.25 \mathrm{U}$ AmpliTaq DNA polymerase (Perkin-Elmer). Thirty-five cycles of amplification were performed at $95^{\circ} \mathrm{C}, 1 \mathrm{~min} ; 48^{\circ} \mathrm{C}, 1 \mathrm{~min}$; and $71^{\circ} \mathrm{C}, 1 \mathrm{~min}$ in a thermocycler (MJ Research). The amplified DNA was fractionated on low-melting agarose, and the products of approximately $450 \mathrm{bp}$ were isolated from the gel, blunt-ended with Klenow enzyme, and ligated into pBluescript (Stratagene) using standard laboratory procedures (Sambrook et al., 1989).

cDNA cloning and genomic fragment isolation. Individual PCR products produced by the degenerate PCR amplification were identified by endonuclease digestion of isolated subclones with the enzymes PleI and NdeII. Unique PCR products were sequenced by the Sanger chain termination method (Sanger et al., 1977) using Sequenase 2.0 (USB). Two specific primers, S1 [5'-TCAGCATCAATACCGCAC-3'] and S2 [5'-TCAGAAACCTTCCAGTCCAG-3'], were used to amplify a 342 bp fragment from the novel subunit sequence identified, which was random prime-labeled with $\alpha^{32} \mathrm{P}$-dCTP and used to screen $2 \times$ $10^{6}$ plaques from a Stratagene brainstem/spinal cord library. Filters were hybridized in $50 \%$ formamide, $2 \times$ saline-sodium citrate (SSC), $1 \%$ sodium dodecyl sulfate $(\mathrm{SDS}), 10 \%$ dextran sulfate, $1 \times$ Denhardt's, and $300 \mu \mathrm{g} / \mathrm{ml}$ salmon sperm DNA at $42^{\circ} \mathrm{C}$ overnight, and then washed under high stringency conditions $\left(0.1 \times \mathrm{SSC}\right.$ at $\left.55^{\circ} \mathrm{C}\right)$. The filters were exposed to Kodak XAR film overnight at $-70^{\circ} \mathrm{C}$ with an intensifying screen. Two clones, which possessed an overlap of 2 kilobases and together spanned the entire open reading frame, were fully sequenced on both strands and ligated together into pBluescript using a unique NcoI site.

A genomic fragment encoding the "TM II" region of $\chi-1$ was obtained by PCR amplification of rat liver DNA with the specific primers S1 and S2 in several separate reactions. TM II has been placed in quotations to denote that recent evidence indicates that it does not traverse the membrane (Hollmann et al., 1994; Wo and Oswald, 1994; Bennett and Dingledine, 1995). Subclones from each of these reactions were independently sequenced.

Northern blot analysis. Total RNA was extracted from rat brain and peripheral tissues using RNAzol B (CINNA/BIOTECX), based on the method of Chomczynski and Sacchi (1987). Total RNA $(20 \mu \mathrm{g})$ was separated on $1 \%$ agarose-formaldehyde gels and transferred to Biotrans(+) nylon membranes (ICN). Membranes were hybridized overnight at $42^{\circ} \mathrm{C}$ with the same $\alpha^{32} \mathrm{P}$-dCTP-labeled fragment used for the library screening. Blots were washed under high stringency and exposed to Kodak XAR film with an intensifying screen. Signals were quantitated on an LKB densitometer (Pharmacia).

${ }^{3} \mathrm{H}$-Kainic acid and ${ }^{3} \mathrm{H}$-CGP 39653 binding assays, The entire open reading frame of $\chi-1$ was subcloned into the BamHI and EcoRV sites in the polylinker of the eukaryotic expression vector $\mathrm{pcDNAI} / \mathrm{Neo}$ (Invitrogen). Human embryonic kidney 293 cells (HEK-293 cells, ATCC CRL 1573) were grown in Earle's minimal essential media containing $10 \%$ fetal bovine sera (GIBCO) and transfected by the calcium phosphate method as per Chen and Okayama (1987), using $20 \mu \mathrm{g}$ of plasmid per $10 \mathrm{~cm}$ plate, with transfection efficiencies of $15-20 \%$. Forty-eight hours after transfection, cell membranes were harvested and ${ }^{3} \mathrm{H}$-kainic acid binding assays were performed as in Werner et al. (1991). For ${ }^{3} \mathrm{H}-\mathrm{CGP} 39653$ binding assays, HEK-293 cells were transfected as above, and cell membranes were prepared as per Sills et al. (1991).

Expression studies in Xenopus oocytes. $\chi^{-1} \mathrm{cDNA}$ was cloned into the BamHI and HindIII sites of pGEMHE (Liman et al., 1992), a high expression vector containing a T7 promoter and the $5^{\prime}$ and $3^{\prime}$ untranslated regions of a Xenopus $\beta$-globin gene. The construct was linearized with SphI prior to transcription with T7 RNA polymerase (Message Machine, Ambion). Xenopus oocytes were prepared as described in Hollmann et al. (1993). The methods for electrophysiology were as in Sullivan et al. (1994), except that calcium was used as the divalent cation in the recording solution. A maximum of $20 \mathrm{ng}$ of cRNA was injected per oocyte. Recordings were performed 2-5 d after injection. Responses to $200 \mu \mathrm{M}$ NMDA were recorded in the presence of $10 \mu \mathrm{M}$ glycine. Mutagenesis of the arginine (AGA codon) residue to a glutamine (CAA codon) residue in the "TM II" region of $\chi^{-1}$ was performed 


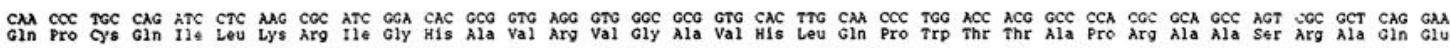

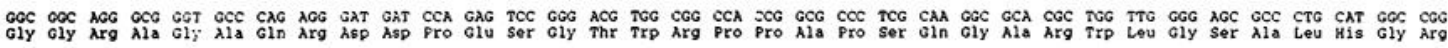
315
105

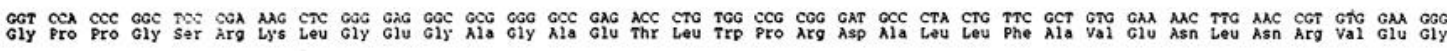
140

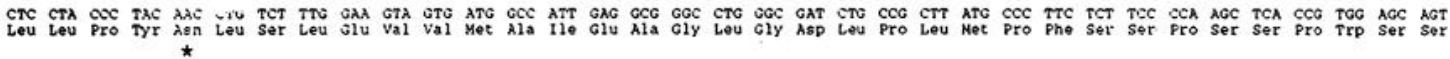

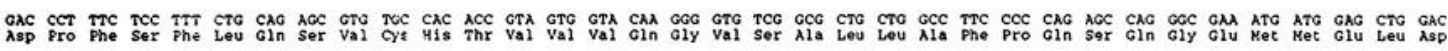

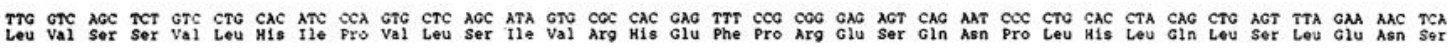

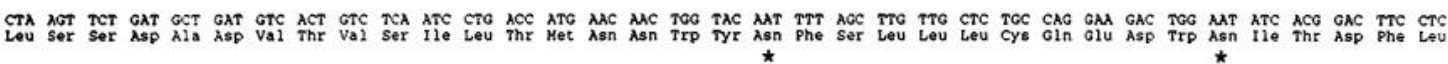

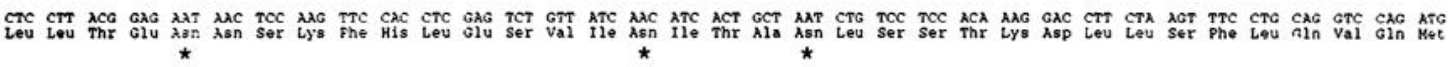

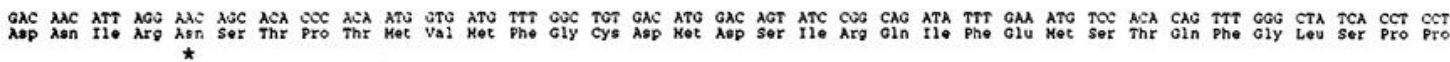

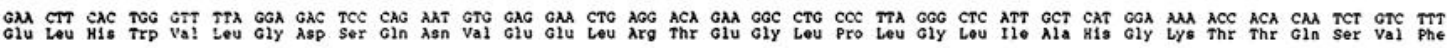

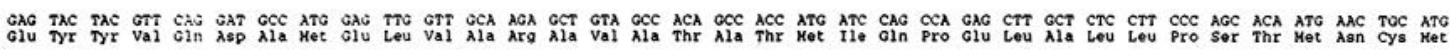

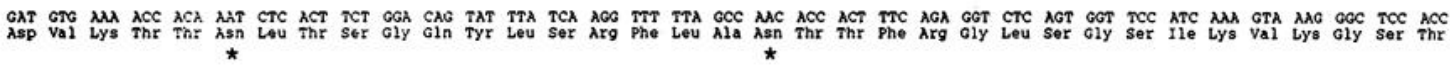

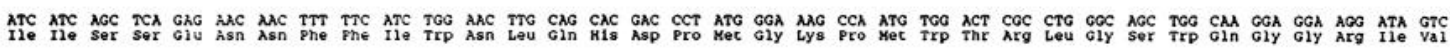

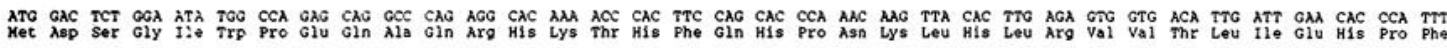

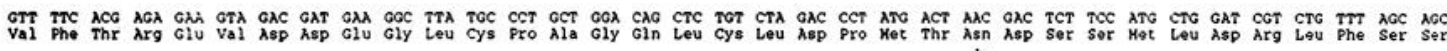
*

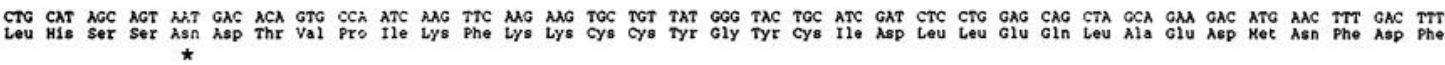

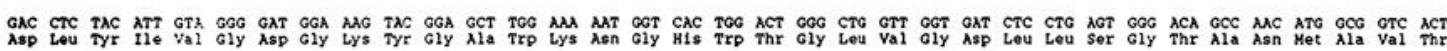

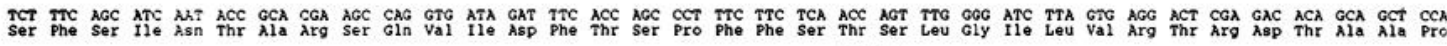

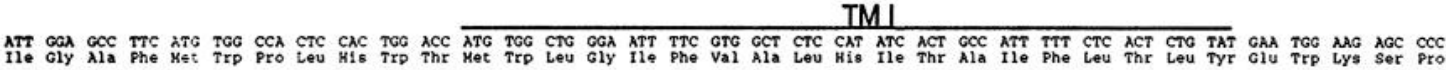
"TM II"

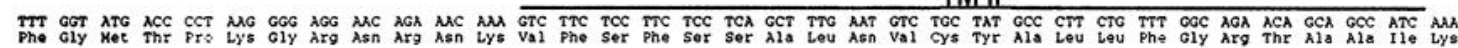
TM III

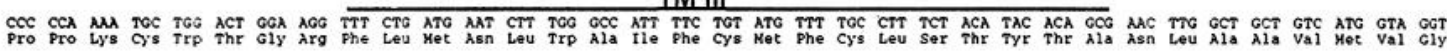

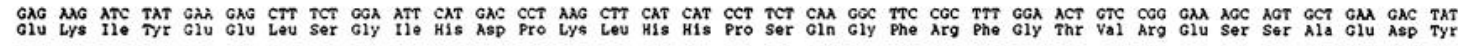

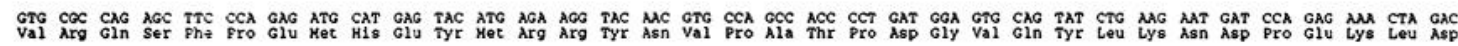

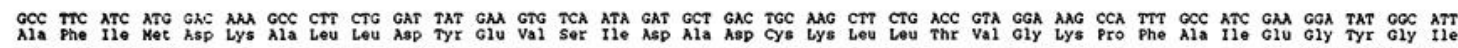

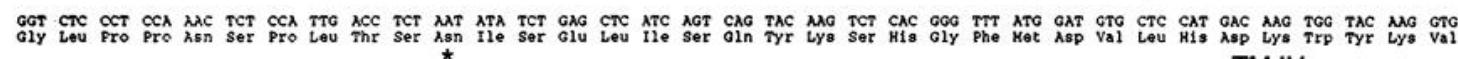

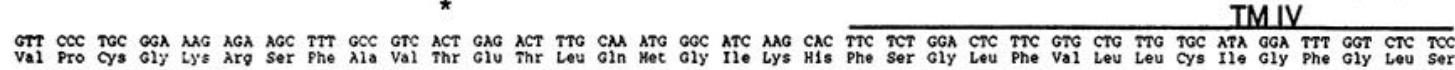

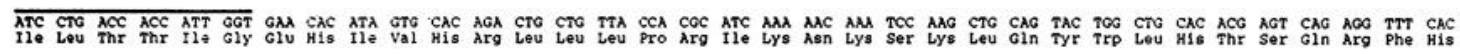

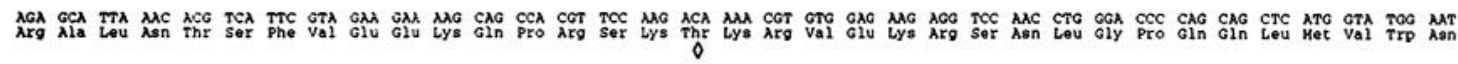

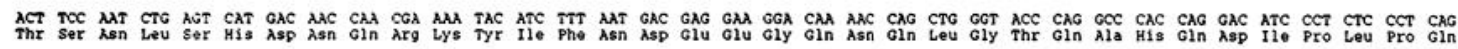

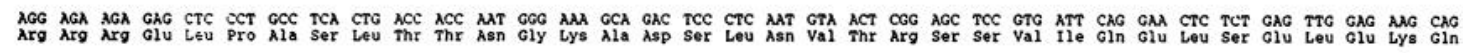

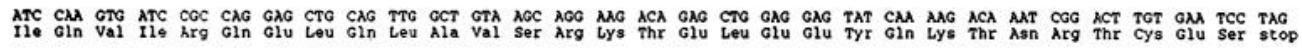

525 630
210 735
245 2840 290 345 $150^{1050}$ ${ }_{385}^{1155}$ $\$ 200$ 1365
455 1490 ${ }_{525}^{1575}$ 560 $\underset{595}{1785}$ 1890
630 $\frac{1995}{665}$ 7100
700 ${ }_{735}^{2205}$ 2310 ${ }_{805}^{2415}$ 2520
840 2625
875 ${ }_{910^{\circ}}^{2730}$ $\underset{945}{2835}$ $980^{2}$ 3045
1015 3150
1050 3255
1085 3945
1115 
as described in Ho et al. (1989). The subcloned insert containing the Inutation was confirmed by sequencing.

In situ hybridization. In situ hybridization was performed as described in Hockfield et al. (1993). Brains or whole embryos were obtained from Sprague-Dawley rats, frozen on dry ice in O.C.T. (Fisher), and stored at $-80^{\circ} \mathrm{C}$ until sectioning. Twelve micrometer sections of tissue were cut in a Reichert-Jung cryostat, thaw-mounted onto ProbeOn slides (Fisher), and fixed immediately with $4 \%$ paraformaldehyde in phosphate-buffered saline (PBS) for $10 \mathrm{~min}$. Slides were then washed in PBS, dehydrated, and stored at $-80^{\circ} \mathrm{C}$ until use. On the day of use, sections were thawed, treated with $0.25 \%$ acetic anhydride in $0.1 \mathrm{M}$ triethanolamine, $\mathrm{pH} 8.0$, and prehybridized for $1 \mathrm{hr}$ at $55^{\circ} \mathrm{C}$ in $50 \%$ formamide, $1 \times$ Denhardt's, $0.6 \mathrm{M} \mathrm{NaCl}, 10 \mathrm{~mm}$ Tris-HCl $\mathrm{pH} 7.5,1$ mM EDTA, $10 \mathrm{~mm}$ dithiothreitol, $500 \mu \mathrm{g} / \mathrm{ml}$ salmon sperm DNA, 500 $\mu \mathrm{g} / \mathrm{ml}$ yeast total RNA, and $50 \mu \mathrm{g} / \mathrm{ml}$ yeast tRNA. $\alpha-{ }^{33}$ P-UTP-labeled cRNA probes were used in these studies because they generated a lower background than $\alpha-{ }^{35} \mathrm{~S}-\mathrm{CTP}$-labeled probes, and the enhanced sensitivity of ${ }^{33}$ P-labeled probes was required to delineate the lower level of $\chi-1$ expression in the adult rat brain. Sense and antisense cRNA probes were generated to the regions corresponding to amino acids $671-739$, 775-846, and 971-1028 using T3 and T7 RNA polymerases. The second probe (amino acids 775-846) produced the least background and was used to generate the figures shown. Hybridizations were performed for $6-8 \mathrm{hr}$ at $55^{\circ} \mathrm{C}$ in prehybridization buffer containing $100 \mu \mathrm{g} / \mathrm{ml}$ salmon sperm DNA, $10 \%$ dextran sulfate, and $1 \times 10^{6} \mathrm{cpm}$ of probe $/ 2$ $\mathrm{cm}^{2}$ of section. Following hybridization, sections were treated with 20 $\mu \mathrm{g} / \mathrm{ml}$ RNAse $\mathrm{A}$ at $37^{\circ} \mathrm{C}$ and then washed twice at $50^{\circ} \mathrm{C}$ in $2 \times \mathrm{SSC}$ for $15 \mathrm{~min}$. Sections were then washed twice at a final stringency of $0.1 \times \mathrm{SSC}$ containing $0.1 \% \beta$-mercaptoethanol at $65^{\circ} \mathrm{C}$ for $15 \mathrm{~min}$. Following dehydration, sections were exposed to Kodax Biomax film for 4-25 d. Sections were stained with cresyl violet and anatomical landmarks were identified using the atlases of Paxinos and Watson (1986) and Paxinos et al. (1991). To analyze the signal at higher resolution, slides were dipped in NTB-2 emulsion (Kodak). After 6 weeks the slides were developed, stained with cresyl violet, and examined under bright-field microscopy. All three antisense probes detected a single $8 \mathrm{~kb}$ transcript on Northern blot analysis and generated identical in situ patterns of expression. Sense probes produced blank autoradiograms at equivalent exposure times. Pretreatment with RNase A or incubation with a 20 -fold molar excess of unlabeled competitor cRNA completely abolished the detected signal, while incubation with unlabeled noncompetitor cRNA had little or no effect.

In vitro translation. Two micrograms of sense cRNA transcribed with T7 RNA polymerase from the pGEMIIE construct were used in a reaction containing $2 \mathrm{mCi} / \mathrm{ml}^{35} \mathrm{~S}-\mathrm{L}-\mathrm{methionine}$ (ICN) and $60 \%$ rabbit reticulocyte lysate according to the manufacturer's instructions (Amersham). The in vitro translation products were separated on a $6 \%$ SDSPAGE gel and examined by autoradiography.

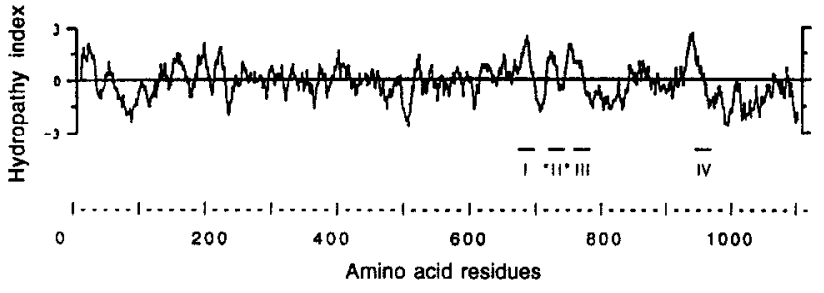

Figure 3. Hydrophobicity profile of $x-1$. The algorithm of Kyte and Doolittle (1982) was used with a window setting of 12 . The calculations were performed using the PEPPLOT program within the University of Wisconsin sequence analysis software (Devereux et al., 1984). Putative transmembrane regions are indicated.

\section{Results}

\section{Identification of a novel glutamate receptor subunit}

Two degenerate oligonucleotide primers designed to recognize conserved sequences of GluR1-7, KA-1, KA-2, and NMDAR1 were used to PCR amplify cDNA synthesized from rat brain mRNA. Restriction digestion of 24 cloned PCR products identified 8 independent restriction patterns. Of these 8 PCR clones, all but one was identified by nucleic acid sequencing as a known glutamate receptor subunit. The deduced amino acid sequence of the novel fragment was $29-36 \%$ identical to other glutamate receptor subunits. Furthermore, the hydrophobicity profile of the novel fragment was very similar to the profiles of the corresponding region of other glutamate receptor subunits, suggesting that this PCR clone might be a fragment of a novel glutamate receptor subunit.

Northern blot analysis using an internal fragment of the isolated PCR product as a probe revealed a single $8 \mathrm{~kb}$ message. Within the adult rat brain, the mRNA was expressed in all regions examined, though at low levels (Fig. $1 A$ ). The message was enriched in the thalamus and spinal cord. No message was detected in any of the peripheral tissues examined (Fig. 1B).

In order to obtain the full coding region of the receptor, we screened a $\lambda$ ZAPII rat brainstem/spinal cord library. Multiple clones spanning the entire open reading frame were obtained and overlapping clones verified the full coding sequence. The

\begin{tabular}{|c|c|c|c|c|c|c|}
\hline & GluR 1-4 & GluR5-7 & KA-1,2 & NMDAR1 & NMDAR2A-D & $\delta 1,2$ \\
\hline GluR5-7 & 40 & & & & & \\
\hline $\mathrm{KA}-1,2$ & 37 & 44 & & & & \\
\hline NMDAR1 & 26 & 28 & 27 & & & \\
\hline NMDAR2A-D & 25 & 24 & 24 & 27 & & \\
\hline$\delta-1,2$ & 29 & 30 & 27 & 26 & 23 & \\
\hline$x-1$ & 23 & 24 & 23 & 27 & 28 & 22 \\
\hline
\end{tabular}

The average percentage identity between two classes was determined by averaging the identities among all pairwise combinations of subunits between two classes. The percentage identity between any given pair of subunits was computed using the GA.P program of the University of Wisconsin sequence analysis software (Devereux et al., 1984).

Figure 2. The deduced amino acid sequence of the rat $\chi-1$ glutamate receptor subunit. Twelve potential glycosylation sites in the predicted extracellular region $\left(^{*}\right)$, and one potential site for $\mathrm{Ca}^{2+} / \mathrm{calmodulin}-d e p e n d e n t$ protein kinase type II $(\diamond)$ in the predicted intracellular region are indicated. Black bars indicate the signal peptide $(S P)$ and the three transmembrane regions in glutamate receptor subunits. Recent evidence suggests that "TM II" does not traverse the membrane as previously thought (Hollmann et al., 1994; Wo and Oswald, 1994; Bennett and Dingledine, 1995). The clcavage site of the signal peptide is predicted by the method of von Heijne (1983). The nucleic acid sequence data will appear in Genbank under the accession number L34938. 
6502 Ciabarra et al. $\cdot$ Cloning of the $\chi-1$ Glutamate Receptor Subunit

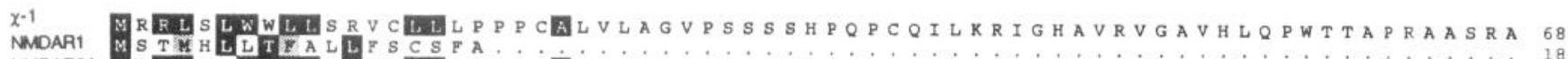

NMDAR2A G

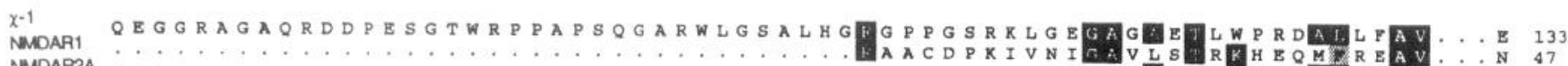

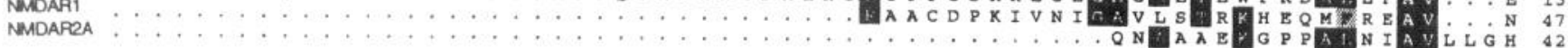

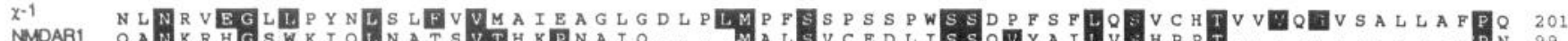

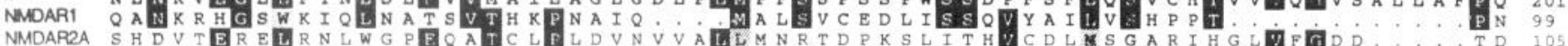

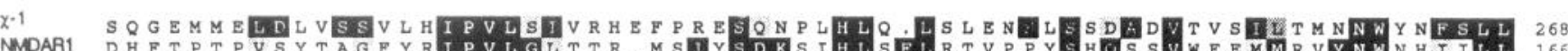

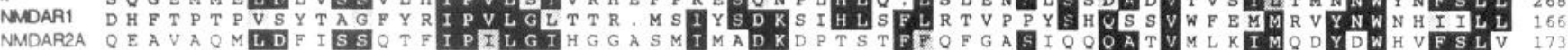

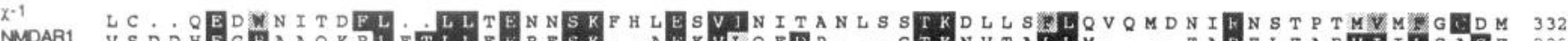

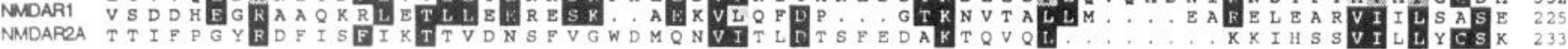

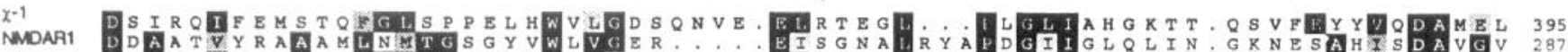

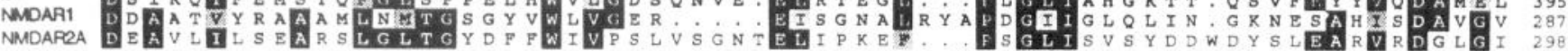

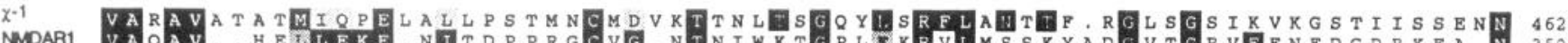

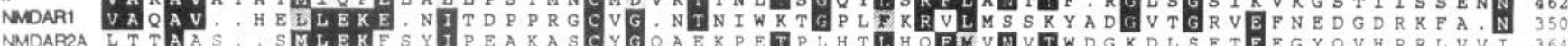

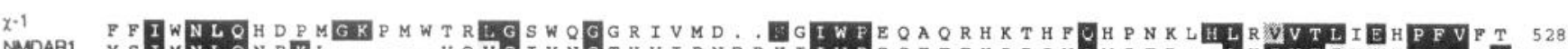

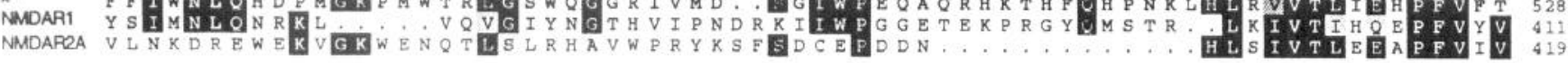

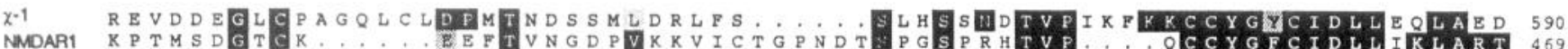

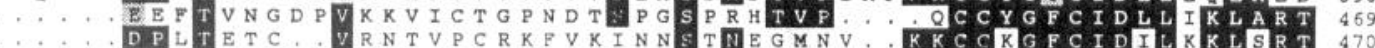

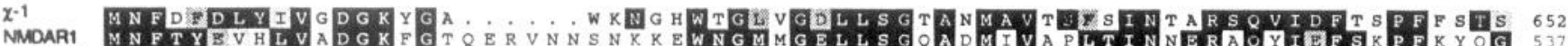

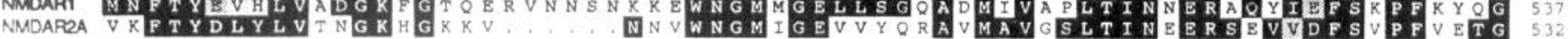
X-1
NMDAR1

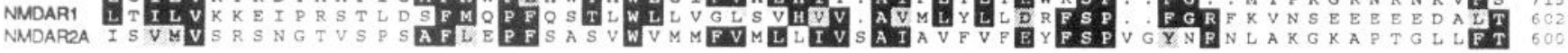

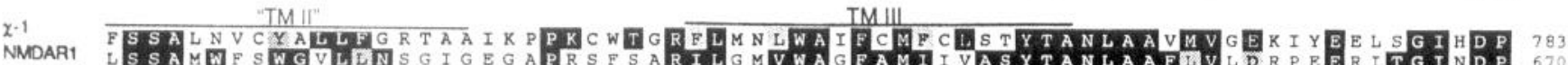

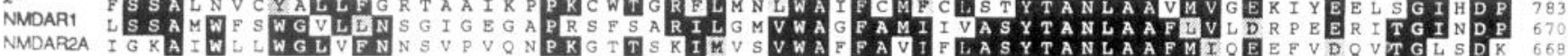

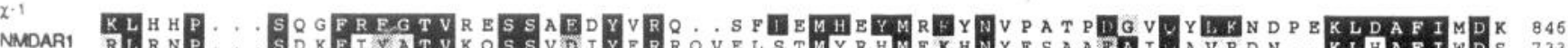

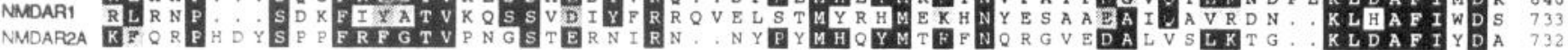

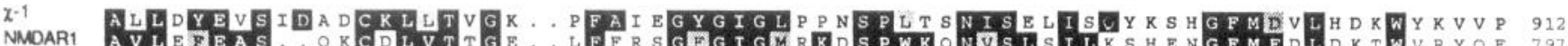

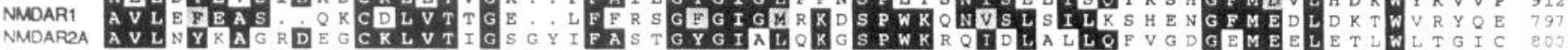

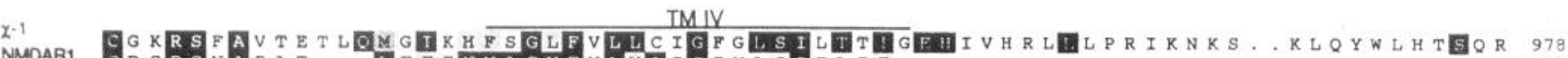

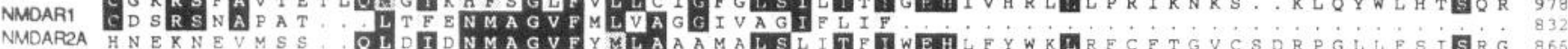

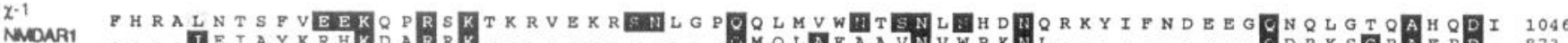

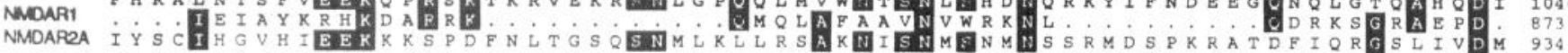

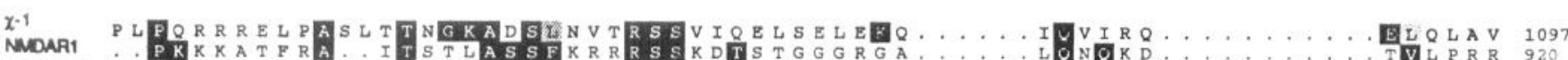
NMDAR1
NMDAREA
$V$

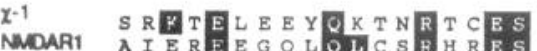
NMOAREA BSIKGNSRPRQLWKKSMESLRQDSLNQN PVSQRDE..... (+412 residues).... SNRRVYKKMPSIESDV 1464

Figure 4. Alignment of the amino acid sequences of $\chi$-1, NMDAR1 (Moriyoshi et al., 1991), and NMDAR2A (Ishii et al., 1993). The putative transmembrane regions are indicated. Identical residues are enclosed in solid boxes, while conservatively related residues are in shaded boxes. The alignment was generated with the PRETTYBOX program within the University of Wisconsin sequence analysis software (Devereux et al., 1984).

translational start site was assigned to the first methionine in the large open reading frame. Since no single clone contained the entire coding region, two clones, which overlapped over an interval of 2 kilobases, were used to construct the full open reading frame for expression studies.
Structural features of $\chi-1$

The open reading frame of $\chi-1$ encodes a protein of 1115 amino acids (Fig. 2) with a calculated molecular weight of $125 \mathrm{kDa}$. The sequence of $\chi-1$ has an average homology of $27 \%$ to NMDA receptor subunits and $23 \%$ to non-NMDA subunits (Ta- 
ble 1). The percent identity between $\chi^{-1}$ and other glutamate receptor subunits $(21-29 \%)$ is similar to the percent identity between other classes of the glutamate receptor family $(23-44 \%)$, and therefore would support the placement of this subunit in a new class within the glutamate receptor family. $\chi-1$ is intermediate in size between the smaller NMDAR1 subunit (938 amino acids) (Moriyoshi et al., 1991) and the larger NMDAR2A-D subunits (1464, 1482, 1250, and 1356 amino acids, respectively) (Ishii et al., 1993).

The amino acid sequence of $\chi-1$ possesses features common to members of the glutamate receptor family, including an $\mathrm{N}$-terminal hydrophobic region encoding a putative signal peptide, and a large $\mathrm{N}$-terminal extracellular domain containing multiple potential sites for glycosylation (Fig. 2). Eleven of the 12 potential glycosylation sites are located in the N-terminal extracellular domain. The $\chi^{-1}$ subunit possesses one potential phosphorylation site for the $\mathrm{Ca}^{2+} /$ calmodulin-dependent protein $\mathrm{ki}$ nase type II (Pearson et al., 1985). Several potential protein kinase C sites (Woodgett et al., 1986) are also present in the putative intracellular regions of $\chi-1$. The hydrophobicity profile of $\chi-1$ is similar to the profiles reported for other glutamate receptor subunits (Fig. 3).

An additional feature common to all ionotropic glutamate receptors, including $\chi^{-1}$, is homology of the region upstream of TM I (amino acids 513-661) to the periplasmic glutamine binding protein of $E$. coli, which is thought to encode the glutamate binding domain (Nakanishi et al., 1990; Stern-Bach et al., 1994). In non-NMDA subunits this region is approximately 115 amino acids, but in all NMDA subunits and in $\chi^{-1}$, this region is approximately 145 amino acids, indicating that $\chi-1$ may be more structurally related to the NMDA class of subunits. Further supporting this possibility, the C-terminus of $\chi-1$ (ELEEYQKTNRTCES) shares homology with the C-terminus of NMDAR1 (EREEGQLQLCSRHRES). C-terminal homology between functionally related glutamate subunits is seen with NMDAR2A-D (Ishii et al., 1993), GluR2 and GluR3 (Boulter et al., 1990; Keinanen et al., 1990; Nakanishi et al., 1990; Sakimura et al., 1990), and GluR5 and GluR6 (Bettler et al., 1990; Egebjerg et al., 1991; Sommer et al., 1992). An alignment of $\chi-1$, NMDAR1, and NMDAR2A is shown in Figure 4.

The "TM II" segment (see Fig. 2 caption) of glutamate-gated channels is thought to control ion selectivity of the channel (Betz, 1990). The "TM II" regions of GluR2, GluR5, and GluR6 contain a site termed the glutamine(Q)/arginine(R) site, which influences the ion permeability of these subunits (Hume et al., 1991; Sommer et al., 1991). The genomic sequence of all three subunits contains a glutamine codon in the Q/R site. However, mRNA transcripts encoding an arginine codon in the $\mathrm{Q} / \mathrm{R}$ site can be generated by RNA editing (Sommer et al., 1991). The most striking feature of the "TM II" region of $\chi-1$ is the presence of an arginine residue. Analysis of the genomic sequence encoding the "TM II" region of $\chi-1$ revealed that the arginine residue is encoded by the genomic sequence, and therefore is not a result of RNA editing. Accordingly, $\chi^{-1}$ is the first glutamate subunit to possess an unedited arginine residue in the "TM II" region.

\section{Distribution of $\chi^{-1} \mathrm{mRNA}$ during development}

Parasagittal sections of rat embryos ages E15 and E19, and horizontal sections of brains from postnatal day 1 (P1), P7, P14, and adult rats were examined by in situ hybridization using antisense riboprobes specific for the coding sequence of the $\chi^{-1}$
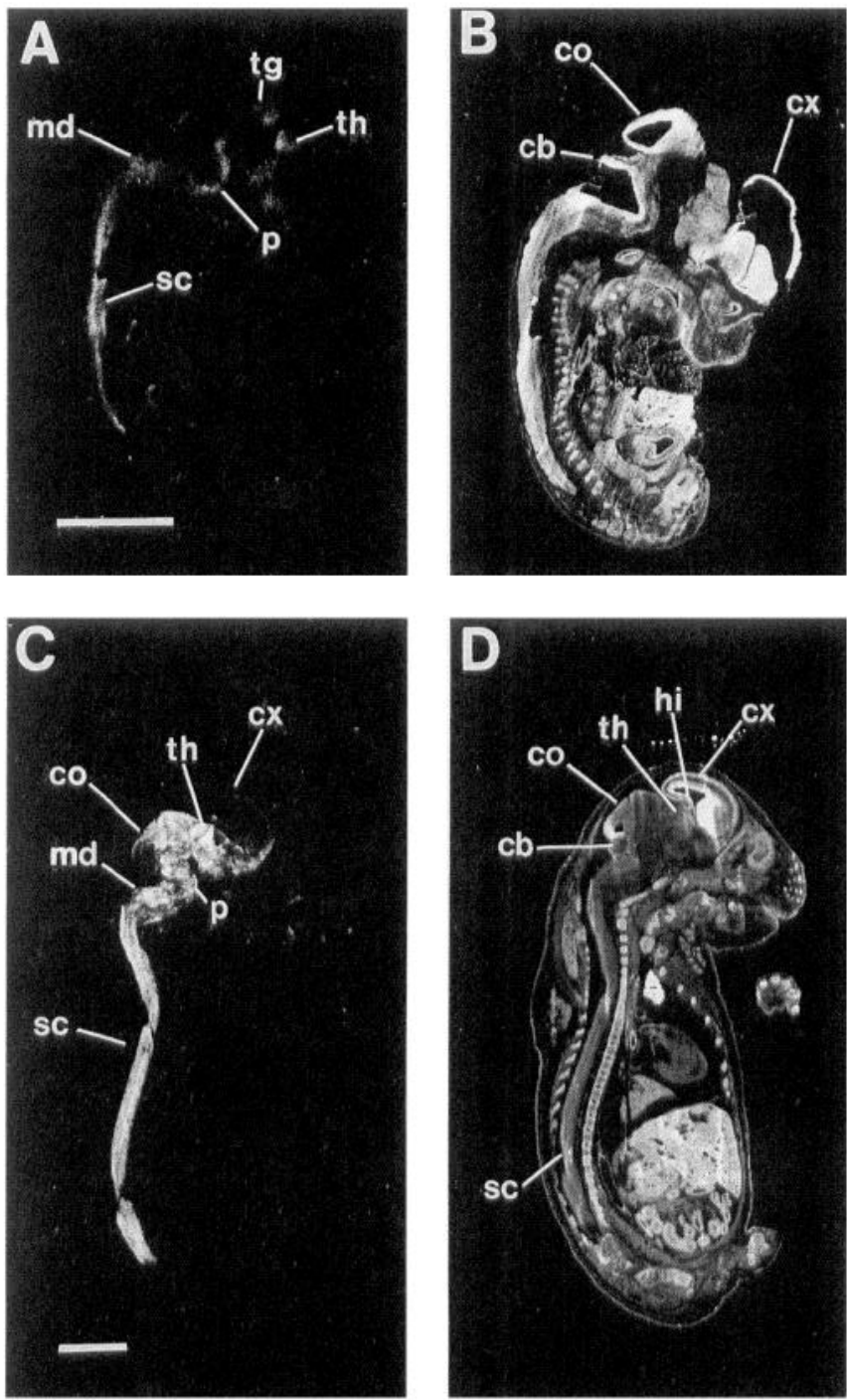

Figure 5. The distribution of $\chi-1 \mathrm{mRNA}$ in E15 and E19 rat embryos. Sagittal sections of E15 $(A)$ and $\mathrm{E} 19(C)$ embryos were hybridized to a ${ }^{33} \mathrm{P}$-labeled antisense RNA probe. Nissl (cresyl violet) stained sections of E15 $(B)$ and E19 $(D)$ embryos are shown for comparison. Abbreviations: $c b$, cerebellum; $c o$, fetal colliculi; $s c$, spinal cord; $c x$, cortical neuroepithelium; $h i$, fetal hippocampus; $m d$, medulla; $p$, pons; $t g$, tegmentum; th, thalamus. Scale bars, $3 \mathrm{~mm}$.

transcript. $\chi-1$ transcripts were detected at E15, the earliest developmental stage examined (Fig. 5). In E15 embryos, $\chi-1$ transcripts were detected in the spinal cord, medulla, pons, tegmentum, thalamus, and hypothalamus. $\chi^{-1}$ transcripts were also detected in peripheral ganglia. Transcripts were not detected in the hippocampus, cortical neuroepithelium, or cerebellar neuroepithelium.

In E19 embryos, $\chi$ - 1 signal intensity increased and displayed a similar but expanded spatial distribution compared to E15 embryos (Fig. 5). Transcripts were detected throughout the spinal cord, brainstem, hypothalamus, and thalamus. $\chi-1$ transcripts were now also detected at lower levels in the hippocampus and the outer layer of the cortical neuroepithelium. Transcripts were not detected in the striatum or cerebellum.

$\chi-1$ transcript levels remained elevated during the first postnatal week (Figs. 6, 7). In horizontal sections of P1 brains, $\chi-1$ transcripts are abundant in several thalamic nuclei, the CA1 field 


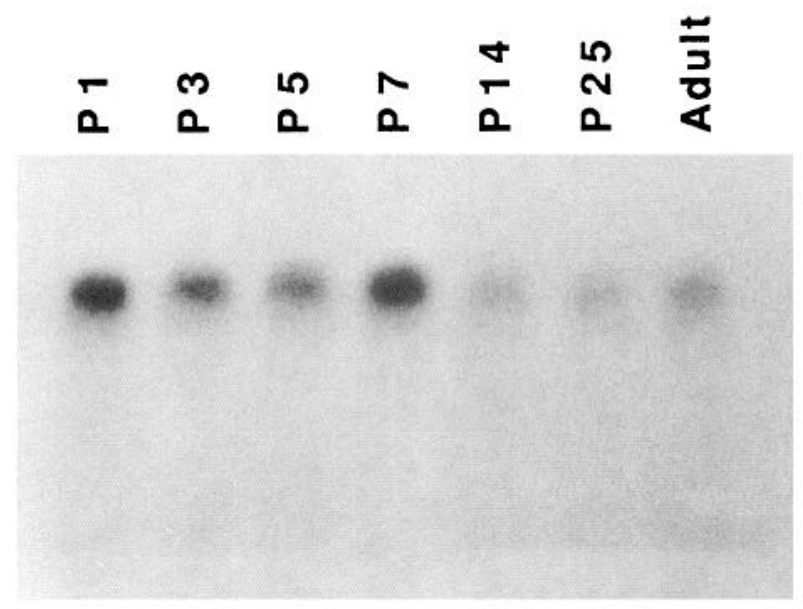

Figure 6. $\chi$-1 mRNA expression during postnatal development. Fifteen micrograms of total RNA extracted from whole brain on postnatal day $1,3,5,7,14,25$, and adult brain were run on a formaldehydeagarose gel and transferred to nylon membranes. Following hybridization with a ${ }^{32} \mathrm{P}$-labeled probe and exposing to film for $2 \mathrm{~d}$ with a screen, the signal was quantitated by densitometry.

of the hippocampus, the colliculi, entorhinal cortex, central gray, and inner and outer layers of the cortex. The spatial distribution of $\chi-1$ remains similar from $\mathrm{P} 1$ to the adult brain. Sections from P7 brains revealed a similar, equally intense pattern of distribution compared to P1 brains.

Examination of emulsion-dipped slides from P7 brains revealed that the pyramidal cell layer of CA1, but not CA3, is strongly labeled (Fig. $8 A$ ). In the thalamus, labeling of large cells, presumably neurons, is heterogeneous with a subpopulation of cells being strongly labeled (Fig. $8 B$ ). Layers II-VI of the cortex also possess a subpopulation of cells which are strongly labeled (data not shown).

There is a sharp decline in $\chi^{-1}$ transcript levels by P14, and levels remain attenuated into adulthood (Figs. 6, 7). Quantitation of $\chi-1$ transcript levels from the Northern blot analysis revealed that $\chi-1$ transcripts are fourfold more abundant in P1 brain than in adult brain.

\section{Distribution of $\chi^{-1} \mathrm{mRNA}$ in the adult rat brain}

In general, regions expressing $\chi^{-1}$ subunit mRNA during development exhibit lower but detectable levels of $\chi^{-1}$ transcripts in the adult rat brain. The highest density of $\chi-1$ mRNA expression in the adult rat brain is in the thalamus and amygdala (Fig. 9). Within the thalamus, the central medial, intermediodorsal, and paraventricular thalamic nuclei possess the highest levels of $\chi-1$ mRNA. $\chi^{-1}$ transcripts are also detected in several other thalamic nuclei including the reticular thalamus. Within the amygdala, the posteroventral medial amygdaloid nucleus and the posterolateral cortical amygdaloid nucleus show the highest transcript levels. In the adult, deep cortical layers exhibit higher transcript levels than superficial layers. The hypothalamus, central gray, colliculi, and pontine nuclei also express $\chi^{-1}$ transcripts. In contrast to the high signal intensity observed in the CAl field of the hippocampus during the early postnatal period, the adult CA1 region possesses a very low level of $\chi-1$ transcripts. Within the adult rat spinal cord, $\chi-1$ transcripts were detected throughout the gray matter with a predominance in laminae 2 and 3 of the dorsal horn (Fig. 10).

\section{Functional expression and ligand binding studies}

Functional expression studies with $\chi-1$ mRNA injected into Xenopus oocytes did not demonstrate agonist-activated currents when 50-1000 $\mu \mathrm{M}$ glutamate, $300 \mu \mathrm{M}$ kainate, or $200 \mu \mathrm{M}$ NMDA was administered. In addition, no responses were obtained using $200 \mu \mathrm{M}$ of the neurotransmitter candidate L-homocysteic acid. Many glutamate receptor subunits, including GluR5(R), GluR7, KA-1, KA-2, NMDAR2A-D, $\delta-1$, and $\delta-2$, fail to produce currents when expressed in a homomeric fashion. Therefore, we tested pairwise combinations of $\chi-1$ and a member from every other class of glutamate receptor subunits. Pairwise expression of $\chi-1$ with NMDAR2B, NMDAR2D, GluR1, GluR6, KA-1, and $\delta-1$ either failed to generate agonist-activated currents or failed to increase the underlying current generated by the coexpressed subunit. However, $\chi-1$ markedly diminished heteromeric NMDAR1/2B and NMDAR1/2D receptor channel currents (Table 2). To specifically examine the interaction of $\chi-1$ with NMDAR1, we coexpressed $\chi-1$ with NMDAR 1 alone. $\chi-1$ significantly diminished NMDAR 1 channel currents activated by NMDA (Table 2) or glutamate (data not shown). In contrast, $\chi-1$ did not affect kainate or glutamate-gated currents through homomeric GluR1 or GluR6 channels (Table 2).

Since the edited forms of GluR2 and GluR5, which contain an arginine in the "TM II" region, display little or no current when expressed in a homomeric configuration (Hume et al., 1991; Sommer et al., 1992), we constructed a mutant of $\chi-1$,
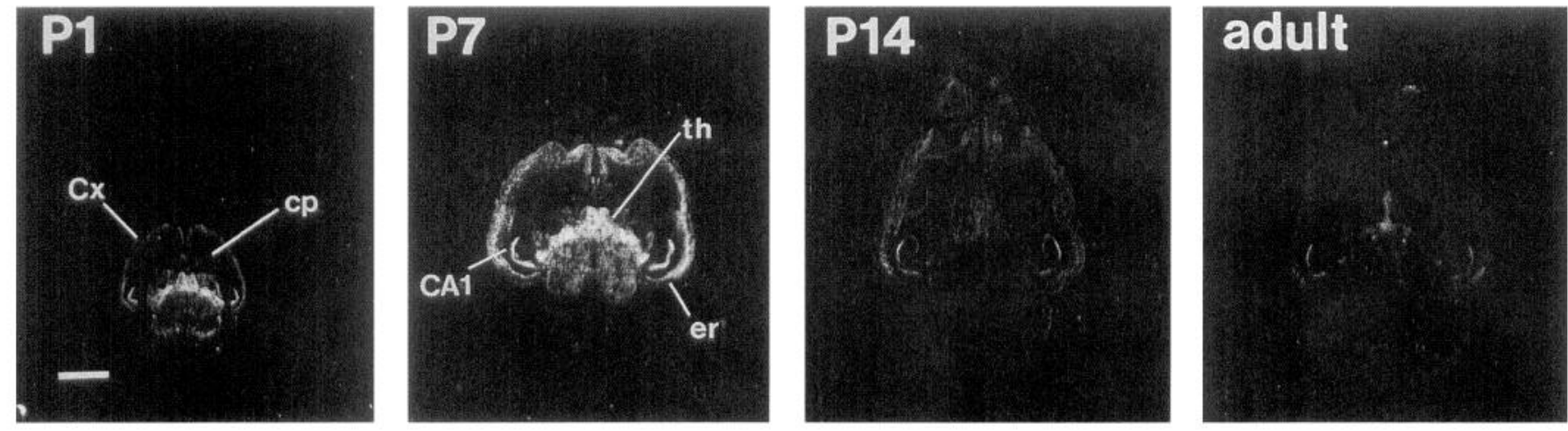

Figure 7. $\chi^{-1}$ expression in the brains of $\mathrm{P} 1, \mathrm{P} 7, \mathrm{P} 14$, and the adult rat as revealed by in situ hybridization. Horizontal sections were hybridized to a ${ }^{3}$ P-labeled antisense RNA probe. Each section was exposed for $6 \mathrm{~d}$. Abbreviations: $C A 1$, CA1 field of the hippocampus; $c p$, caudate-putamen; $C x$, cerebral cortex; $e r$, entorhinal cortex; $t h$, thalamus. Scale bar, $3 \mathrm{~mm}$. 

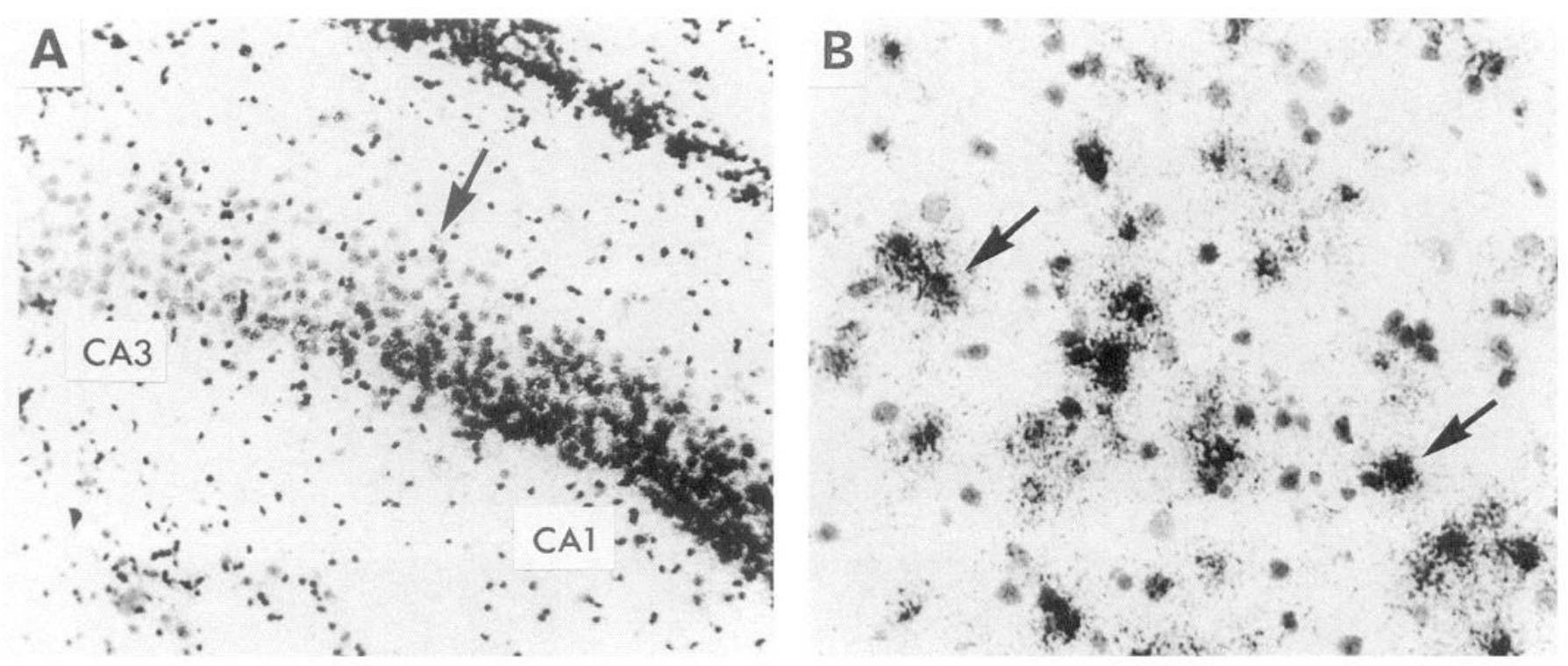

Figure 8. High resolution bright-field microscopy of emulsion-dipped sections from P7 brain stained with cresyl violet. A, Expression of $\chi$-1 transcripts in the CA1 and CA3 hippocampal pyramidal cell layer. The arrow indicates the approximate boundary between the larger, more loosely packed CA3 pyramidal cell layer and the smaller, more densely packed CA1 cell layer. $B$, Expression of $\chi^{-1}$ in the thalamus illustrating the heterogeneity of cellular signal intensity. Arrows indicate examples of strongly labeled cells.

converting the arginine to a glutamine with the aim of enhancing the homomeric channel current. However, the mutated $\chi^{-1}$ did not form glutamate-activated homomeric channels.

The ligand binding of $\chi-1$ was investigated using HEK-293 cells transiently transfected with a eukaryotic expression vector containing the coding sequence of $\chi-1$. Binding of ${ }^{3} \mathrm{H}$-kainate or the NMDA receptor ligand ${ }^{3} \mathrm{H}-\mathrm{CGP} 39653$ (Sills, 1991) to membranes from $x-1$ expressing cells was not detected. Recently, binding of ${ }^{3} \mathrm{H}$-CGP 39653 has been demonstrated to heteromeric NMDAR1/NMDAR2A receptors, but not other homomeric or heteromeric NMDA receptors (Laurie and Seeburg, 1994). We further examined ${ }^{3} \mathrm{H}-\mathrm{CGP} 39653$ binding in HEK-293 cells cotransfected with NMDAR1 and $\chi-1$, but no binding was detected. Northern blot analysis revealed that levels of the $\chi-1$ transcript in the transiently transfected HEK-293 cells were as high as or higher than levels of a GluR6 clone that were sufficient to demonstrate ${ }^{3} \mathrm{H}$-kainate binding (data not shown). To determine if the cloned cDNA could be properly translated, in vitro transcribed cRNA was translated in a reticulocyte lysate system. The $x^{-1}$ cRNA generated a protein of approximately $125 \mathrm{kDa}$, the predicted molecular weight of the mature protein (data not shown).

\section{Discussion}

We have identified a novel member of the ionotropic glutamate receptor family which we have designated $\chi-1$. The $\chi-1$ subunit possesses structural features common to members of the glutamate receptor family. The lack of high homology to previously identified subunits places $\chi^{-1}$ in a new class. Transcripts of the $x^{-1}$ subunit in the rat brain are detected at E15, the earliest stage examined. The spatial distribution of $\chi^{-1}$ subunit expression is similar from P1 to adulthood and includes the spinal cord, brainstem, thalamus, hypothalamus, amygdala, CAl field of the hippocampus, and the cortex. During late embryonic development, $x^{-1}$ transcript levels increase and remain elevated until the second postnatal week, when levels sharply decline. The observed decline in $\chi^{-1}$ transcript levels could be due to either a decrease in cellular expression levels of $\chi-1$ or a decrease in the number of cells expressing the subunit. The majority of neurogenesis in the rat brain takes place from E13-E16 in the thalamus (Altman and Bayer, 1979), from E11-E16 in the spinal cord (Nornes and Das, 1974), and from E16-E19 in the hippocampus (Bayer, 1980). The high levels of the $\chi^{-1}$ transcript during and shortly after neurogenesis in these regions may indicate a role for the $\chi-1$ subunit in early neuronal differentiation, migration, and synapse formation. $\chi^{-1}$ may play a lesser role in mature synapse formation since transcript levels decline before many mature synapses form. For instance, in the cortex, $\chi-1$ transcript levels decrease sharply before a large increase in the synaptic density takes place from P14-P26 (Aghajanian and Bloom, 1967).

Functional expression studies in Xenopus oocytes demonstrated that the $\chi-1$ subunit specifically attenuates currents generated by homomeric and heteromeric NMDA receptors, but not nonNMDA receptors. The mechanism of the observed inhibition of NMDA currents by $\chi-1$ is unknown. It is possible that $\chi-1$ interferes with the translation or assembly of functional NMDA receptor subunits rather than by altering channel properties by coassembly with NMDA subunits. We were unable to directly detect by Western blot analysis NMDAR1 protein from oocytes injected with NMDAR1 RNA, presumably because of low NMDAR1 protein levels. However, immunoprecipitation of a larger quantity of oocyte protein with an NMDAR1 antibody (Pharmingen), allowed the detection of NMDAR1 protein. No difference in NMDAR1 protein levels was observed between oocytes injected with NMDAR1 or NMDAR1/ $\chi^{-1}$ (data not shown). Therefore, a reduction in the translation of NMDAR1 protein does not appear to be mediated by $\chi-1$ RNA coinjection.

If incorporated into the NMDA receptor complex, the apparent inhibitory effect of $\chi-1$ on NMDA-mediated current may be due to a change in channel properties resulting in more rapid desensitization kinetics, lower open probability, or lower conductance of the channel. It is possible that a specific combination 

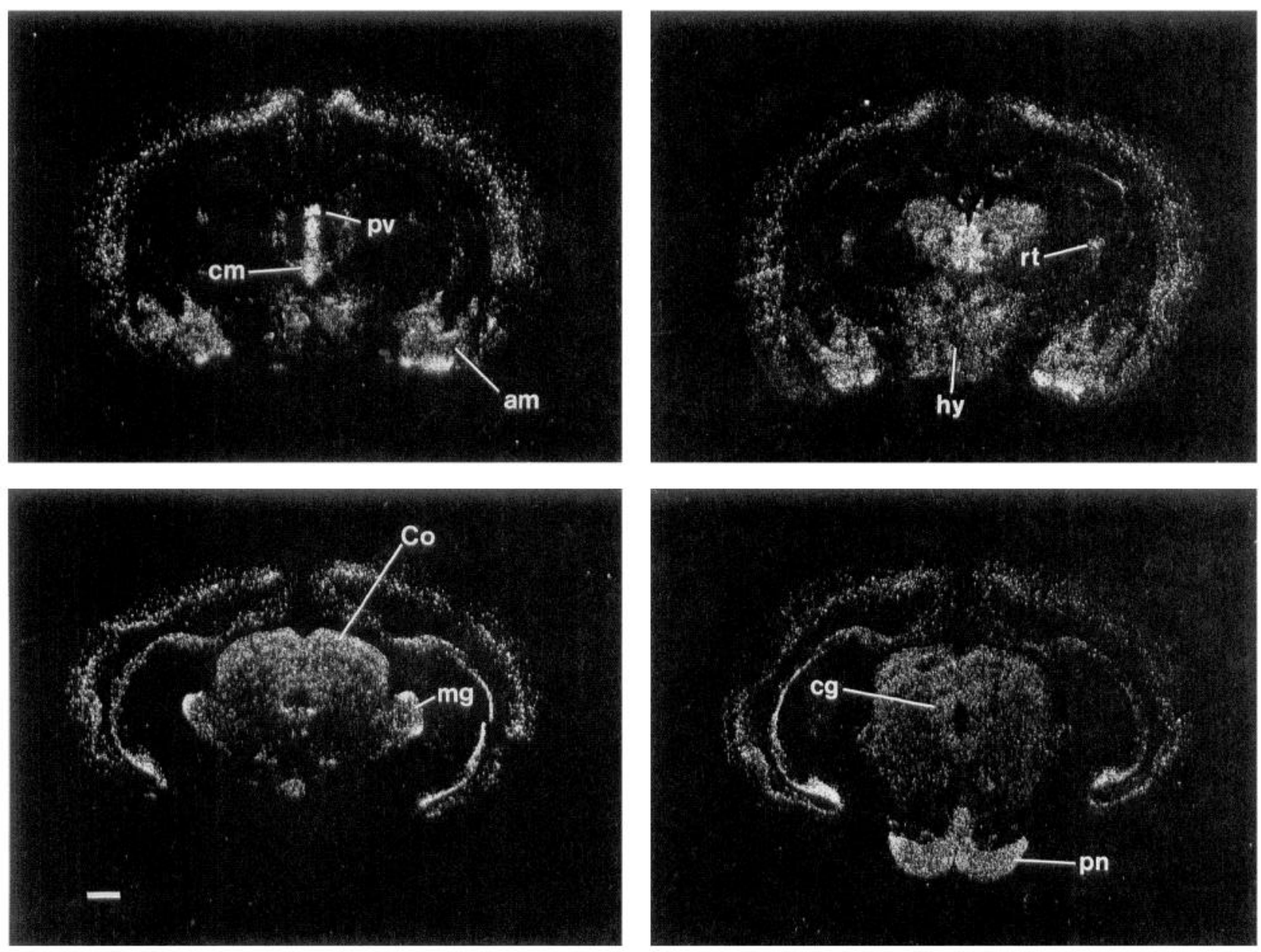

Figure 9. The expression of $\chi-1$ in the adult rat brain. Coronal sections were hybridized to a ${ }^{33}$ P-labeled antisense RNA probe. Exposure times were approximately four times as long as those in Figure 7. Abbreviations: am, amygdala; $C A 1$, CA1 field of the hippocampus; $\mathrm{cm}$, centromedial thalamic nucleus; hy, hypothalamus; $C o$, superior colliculus; $m g$, medial geniculate nucleus; $p n$, pontine nucleus; $p v$, paraventricular thalamic nucleus; $r t$, reticular thalamus. Scale bar, $1 \mathrm{~mm}$.

of subunits, or a yet unidentified subunit, may be necessary for reproducing other properties that the $\chi^{-1}$ subunit may possess. Furthermore, the observed channel properties of $\chi^{-1}$ could be dependent on the expression system. For instance, the particular phosphorylation state of $\chi-1$ in the Xenopus oocyte system may cause $\chi^{-1}$ to diminish currents through NMDA receptors. Investigation of the properties of $\chi-1$ homomeric and heteromeric channels in other expression systems may reveal other functional properties.
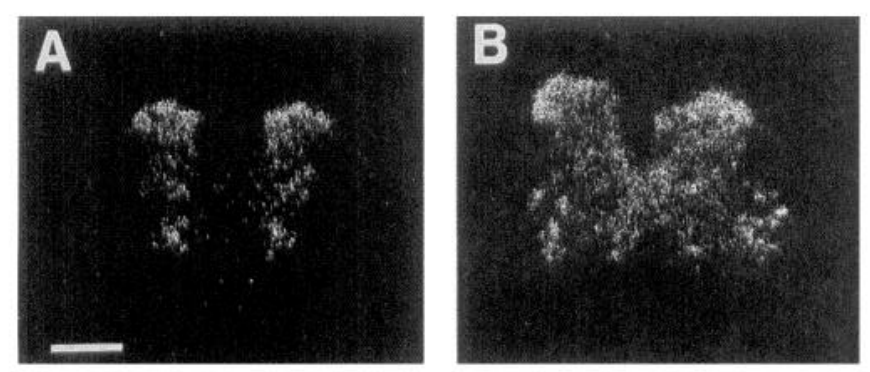

Figure 10. The expression of $\chi-1$ in the adult rat spinal cord. Transverse sections were hybridized to a ${ }^{33} \mathrm{P}$-labeled antisense RNA probe. Cervical $(A)$ and lumbar $(B)$ levels are shown. Scale bar, $1 \mathrm{~mm}$.
An unusual feature of the $\chi^{-1}$ subunit is that it is the first glutamate receptor to possess a genomically encoded arginine residue in the "TM II" region. Based on studies of the other members of the glutamate receptor family, we would expect heteromeric receptors containing $\chi^{-1}$ to possess a low permeability to calcium. AMPA channels formed with the edited GluR2(R) subunit have a low calcium permeability (Hume et al., 1991; Verdoorn et al., 1991). Similarly, an NMDAR1 subunit mutant,

Table 2. Inhibition of NMDA currents by $\chi-1$ in Xenopus oocytes

\begin{tabular}{lcc} 
Receptor injected & $\begin{array}{l}\text { Mean current } \\
(\mathrm{nA} \pm \mathrm{SD})\end{array}$ & $\begin{array}{l}\text { Mean current } \\
\text { with } \chi-1 \\
\text { co-injected }^{a} \\
(\mathrm{nA} \pm \mathrm{SD})\end{array}$ \\
\hline NMDAR1 $^{b}$ & $71 \pm 14, n=6$ & $12 \pm 6, n=6$ \\
NMDAR1/NMDAR2B $^{c / N}$ & $367 \pm 46, n=8$ & $77 \pm 20, n=7$ \\
NMDAR1/NMDAR2D & $53 \pm 40, n=12$ & $0.2 \pm 0.4, n=6$ \\
GluR1 & $197 \pm 37, n=6$ & $203 \pm 25, n=6$ \\
GluR6 & $213 \pm 114, n=5$ & $323 \pm 85, n=6$ \\
\hline
\end{tabular}

a 2 ng of $\chi^{-1}$ cRNA injected.

${ }^{b} 0.5 \mathrm{ng}$ of NMDAR1 cRNA injected.

$0.05-0.25 \mathrm{ng}$ of NMDAR1 cRNA injected. 
containing an arginine instead of an asparagine in the $\mathrm{Q} / \mathrm{R}$ site of "TM II," displays a markedly reduced calcium permeability (Sakurada et al., 1993). In addition, GluR6(R) channels exhibit a decreased calcium permeability compared to GluR6(Q) channels expressed in Xenopus oocytes (Egebjerg and Heinemann, 1993).

Recently, NMDA receptors have been classified into four pharmacological classes whose distributions correlate with the distributions of the four NMDAR2 subunits (Buller et al., 1994). Although binding of $\chi-1$ to ${ }^{3} \mathrm{H}-\mathrm{CGP} 39653$ was not detected, ${ }^{3} \mathrm{H}$-CGP 39653 binding has only been demonstrated for heteromeric NMDAR1/2A receptors (Laurie and Seeburg, 1994). Therefore, it is possible that NMDA receptor ligands specific for other NMDA pharmacological classes may prove useful in defining the binding characteristics of $\chi-1$.

We have presented the sequence and characterized the structural features and mRNA distribution of a novel member of the glutamate receptor family which may interact with NMDA receptor subunits. The temporal expression of this subunit indicates that it may play a role in early neuronal differentiation, migration, and synapse formation. Additional biochemical and electrophysiological studies will be needed to elucidate further the role of this subunit in glutamate neurotransmission.

\section{Note added in proof}

During the course of this work we learned that a clone identical to $\chi^{-1}$ had been obtained independently and named NMDAR-L by Sucher et al. (1995). The two groups generated data largely in accord, communicated their results freely with one another, and now publish the work as contiguous articles.

\section{References}

Aghajanian GK, Bloom FE (1967) The formation of synaptic junctions in developing rat brain: a quantitative electron microscopy study. Brain Res 6:716-727.

Altman J, Bayer SA (1979) Development of the diencephalon in the rat. J Comp Neurol 188:455-472.

Balazs R, Hack N, Jorgensen OS, Cotman CW (1989) N-methyl-Daspartate promotes the survival of cerebellar granule cells: pharmacological characterization. Neurosci Lett 101:241-246.

Bayer SA (1980) Development of the hippocampal region in the rat. I. neurogenesis examined with ${ }^{3} \mathrm{H}$-thymidine autoradiography. $\mathrm{J}$ Comp Neurol 190:87-114.

Bennett JA, Dingledine R (1995) Topology profile for a glutamate receptor: three transmembrane domains and a channel-lining reentrant membrane loop. Neuron 14:373-384.

Bettler B, Boulter J, Hermans-Borgmeyer I, O'Shea-Greenfield A, Deneris ES, Moll C, Borgmeyer U, Hollman M, Heinemann S (1990) Cloning of a novel glutamate receptor subunit, GluR5: expression in the nervous system during development. Neuron 5:583-595.

Betz H (1990) Ligand gated channels in the brain: the amino acid receptor superfamily. Neuron 5:383-392.

Blackstone CD, Moss SJ, Martin LJ, Levey AI, Price DL, Huganir RL (1992) Biochemical characterization and localization of a non- $N$ methyl-D-aspartate glutamate receptor in rat brain. $J$ Neurochem 58 : $1118-1126$.

Bliss T, Collingridge GL (1993) A synaptic model of memory: long term potentiation in the hippocampus. Nature 361:31-39.

Boulter J, Hollman M, Oshea-Greenfield A, Hartley M, Deneris E, Maron C, Heinemann S (1990) Molecular cloning and functional expression of glutamate receptor subunit genes. Science 249:10331037.

Brewer G, Cotman CW (1989) NMDA receptor regulation of neuronal morphology in cultured hippocampal neurons. Neurosci Lett 99:268273.

Brose N, Gasic GP, Vetter DE, Sullivan JM, Heinemann SF (1993) Protein chemical characterization and immunocytochemical localization of the NMDA receptor subunit NMDA R1. J Biol Chem 268: 22663-22671.
Buller AL, Larson HC, Schneider BE, Beaton JA, Morrisett RA, Monaghan DT (1994) The molccular basis of NMDA receptor subtypes: native receptor diversity is predicted by subunit composition. J Neurosei 14:5471-5484.

Chazot PL, Coleman SK, Cik M, Stephenson FA (1994) Molecular characterization of $N$-methyl-D-aspartate receptors expressed in mammalian cells yields evidence for the coexistence of three subunit types within a discrete receptor molecule. J Biol Chem 269:24403-24409.

Chen C, Okayama H (1987) High-efficiency transformation of mammalian cells by plasmid DNA. Mol Cell Biol 7:2745-2752.

Choi DW (1988) Glutamate neurotoxicity and diseases of the nervous system. Neuron 1:623-634.

Chomczynski P, Sacchi N (1987) Single-step method of RNA isolation by acid guanidinium thiocyanate-phenol-chloroform extraction. Anal Biochem 162:156-159.

Collingridge GL, Lester RAJ (1989) Excitatory amino acid receptors in the vertebrate central nervous system. Pharmacol Rev 40:143-210.

Devereux J, Haeberli P, Smithies O (1984) A comprehensive set of sequence analysis programs for the VAX. Nucleic Acids Res 12:387395 .

Egebjerg J, Heinemann SF (1993) $\mathrm{Ca}^{2+}$ permeability of unedited and edited versions of the kainate selective glutamate receptor GluR6. Proc Natl Acad Sci USA 90:755-759.

Egebjerg J, Bettler B, Hermans-Borgmeyer I, Heinemann S (1991) Cloning of a cDNA for a glutamate receptor subunit activated by kainate but not AMPA. Nature 351:745-748.

Ho SN, Hunt HD, Horton RM, Pullen JK, Pease LR (1989) Site-directed mutagenesis by overlap extension using the polymerase chain reaction. Gene 77:51-59.

Hockfield S, Carlson S, Evans C, Levitt P, Pintar J, Silberstein L (1993) Molecular probes of the nervous system: selective methods for antibody and nucleic acid probes. Cold Spring Harbor, NY: Cold Spring Harbor Laboratory.

Hollmann M, Heinemann S (1994) Cloned glutamate receptors. Annu Rev Neurosci 17:31-108.

Hollmann M, Boulter J, Maron C, Beasley L, Sullivan J, Pecht G, Heinemann S (1993) Zinc potentiates agonist-induced currents at certain splice variants of the NMDA receptor. Neuron 10:943-954.

Hollmann M, Maron C, Heinemann S (1994) N-glycosylation site taggings suggests a three transmembrane domain topology for the glutamate receptor GluR1. Neuron 13:1331-1343.

Hume RI, Dingledine R, Heinemann SF (1991) Identification of a site in glutamate receptor subunits that controls calcium permeability. Science 253:1028-1031.

Ikeda K, Nagasawa M, Mori H, Araki K, Sakimura K, Watanabe M, Inoue $Y$, Mishina $M$ (1992) Cloning and expression of the $\epsilon 4$ subunit of the NMDA receptor channel. FEBS Lett 313:34-38.

Ishii T, Moriyoshi K, Sugihara H, Sakurada K, Kadotani H, Yokoi M, Akazawa C, Shigemoto R, Mizuno N, Masu M, Nakanishi S (1993) Molecular characterization of the family of the $N$-methyl-D-aspartate receptor subunits. J Biol Chem 268:2836-2843.

Keinanen K, Wisden W, Sommer B, Werner P, Herb A, Verdoorn TA, Sakmann B, Seeburg PH (1990) A family of AMPA-selective glutamate receptors. Science 249:556 560 .

Komoru H, Rakic P (1993) Modulation of neuronal migration by NMDA receptors. Science 260:95-97.

Kutsuwada T, Kashiwabuchi N, Mori H, Sakimura K, Kushiya E, Araki K, Meguro H, Masaki H, Kumanishi T, Arakawa M, Mishina M (1992) Molecular diversity of the NMDA receptor channel. Nature $358: 36-41$.

Kyte J, Doolittle RF (1982) A simple method for displaying the hydropathic character of a protein. J Mol Biol 157:105-132.

Laurie DJ, Seeburg PH (1994) Ligand affinities at recombinant $N$-methyl-D-aspartate receptors depend on subunit composition. Eur J Pharmacol 268:335 345 .

Liman ER, Tygat J, Hess P (1992) Subunit stoichiometry of a mammalian $\mathrm{K}^{+}$channel determined by construction of multimeric cDNAs. Neuron 9:861-871.

Malenka RC (1994) Synaptic plasticity in the hippocampus: LTP and LTD. Cell 78:535-538.

Marti T, Benke D, Mertens S, Heckendorn R, Pozza M, Allgeier H, Angst C, Laurie D, Seeburg P, Mohler H (1993) Molecular distinction of three $N$-methyl-D-aspartate-receptor subtypes in situ and developmental receptor maturation demonstrated with the photoaffinity 
ligand ${ }^{125}$ I-labeled CGP 55802A. Proc Natl Acad Sci USA 90:8434 8438.

McDonald JW, Johnston MV (1990) Physiological and pathophysiological roles of excitatory amino acids during central nervous system development. Brain Res Rev 15:41-70.

Meguro H, Mori H, Araki K, Kushiya E, Kutsuwada T, Yamazaki M, Kumanishi T, Arakawa M, Sakimura K, Mishina M (1992) Functional characterization of a heteromeric NMDA receptor channel expressed from cloned cDNAs. Nature 357:70-74.

Monaghan DT, Bridges RJ, Cotman CW (1989) The excitatory amino acid receptors: their classes, pharmacology, and distinct properties in the function of the central nervous system. Annu Rev Pharmacol Toxicol 29:365-402.

Monyer H, Sprengel R, Schoepfer R, Herb A, Higuchi M, Lomeli H, Burnashev N, Sakmann B, Seeburg PH (1992) Heteromeric NMDA receplors: molecular and functional distinction of subtypes. Science 256:1217-1221.

Moriyoshi K, Masu M, Ishii T, Shigemoto R, Mizuno N, Nakanishi S (1991) Molecular cloning and characterization of the rat NMDA receptor. Nature 354:31-37.

Nakanishi N. Shneider NA, Axel R (1990) A family of glutamate receptor genes: evidence for the formation of heteromultimeric receptors with distinct channel properties. Neuron 5:569-581.

Nakanishi N, Axel R, Shneider NA (1992) Alternative splicing generates functionally distinct $N$-methyl-D-aspartate receptors. Proc Natl Acad Sci USA 89:8552-8556.

Nornes HO, Das GD (1974) Temporal pattern of neurogenesis in the spinal cord of rat. I. An autoradiographic study-time and sites of origin and migration and settling patterns of neuroblasts. Brain Res 73:121-138.

Olney JW (1990) Excitotoxic amino acids and neuropsychiatric disorders. Annu Rev Pharmacol Toxicol 30:47-71.

Paxinos G, Watson C (1986) The rat brain in stereotaxic coordinates, 2nd ed. Sydney: Academic.

Paxinos G, Tork I, Tecott LH, Valentino KL (1991) Atlas of developing rat brain. San Diego: Academic.

Pearson RB, Woodgett JR, Cohen P, Kemp BE (1985) Substrate specificity of a multifunctional calmodulin-dependent protein kinase. $\mathrm{J}$ Biol Chem 260:14471-14476.

Sakimura K, Bujo H, Kushiya E, Araki K, Yamazaki M, Yamazaki M, Meguro H, Warashina A, Numa S, Mishina M (1990) Functional expression from cloned cDNAs of glutamate receptor species responsive to kainate and quisqualate. FEBS Lett 272:73-80.

Sakurada K, Masu M, Nakanishi S (1993) Alteration of $\mathrm{Ca}^{2+}$ permeability and sensitivity to $\mathrm{Mg}^{2+}$ and channel blockers by a single amino acid substitution in the $N$-methyl-D aspartate receptor. J Biol Chem 268:410-415.

Sambrook J, Fritsch EF, Maniatis T (1989) Molecular cloning: a lab- oratory manual. Cold Spring Harbor, NY: Cold Spring Harbor Laboratory.

Sanger F, Nicklen S, Coulson AR (1977) DNA sequencing with chain terminating inhibitors. Proc Natl Acad Sci USA 74:5463-5467.

Secburg PH (1993) The molecular biology of mammalian glutamate receptor channels. Trends Neurosci 16:359-365.

Sills MA, Fagg G, Pozza M, Angst C, Brundish DE, Hurt SD, Wilusz EJ, Williams M (1991) $\left[{ }^{3} \mathrm{H}\right] \mathrm{CGP} 39653$ : a new $N$-methyl-v-aspartate antagonist radioligand with low nanomolar affinity in brain. Eur $\mathbf{J}$ Pharmacol 192:19-24.

Sommer B, Kohler M, Sprengel R, Seeburg PH (1991) RNA editing in brain controls a determinant of ion flow in glutamate-gated channels. Cell 67:11-19.

Sommer B, Burnashev N, Verdoorn T, Keinanen K, Sakmann B, Seeburg PH (1992) A glutamate receptor channel with high affinity for domoate and kainate. EMBO J 11:1651-1656.

Stern-Bach Y, Bettler B, Hartley M, Sheppard PO, O'Hara PJ, Heinemann SF (1994) Agonist selectivity of glutamate receptors is specified by two domains structurally related to hacterial amino acidbinding proteins. Neuron 13:1345-1357.

Sucher NJ, Akbarian S, Chi CL, Leclerc CL, Awobuluyi M, Deitcher DL, Wu MK, Yuan JP, Jones EG, Lipton SA (1995) Developmental and regional expression pattern of a novel NMDA receptor-like subunit (NMDAR-L) in the rodent brain. J Neurosci 15:6509-6520.

Sullivan JM, Traynelis SF, Chen HV, Escobar W, Hcinemann SF, Lipton SA (1994) Identification of two cysteine residues that are required for redox modulation of the NMDA subtype of glutamate receptor. Neuron 13:929-936.

Verdoorn TA, Burnashev N, Monyer H, Seeburg PH, Sakmann B (1991) Structural determinants of ion flow through recombinant glutamate receptor channels. Science 252:1715-1718.

von Heijne G (1983) Patterns of amino acids near signal-sequence cleavage sites. Eur J Biochem 133:17-21.

Wenthold RJ, Yokotani N, Doi K, Wada K (1992) Immunochemical characterization of the non-NMDA glutamate receptor using subunitspecific antibodies. J Biol Chem 268:501-507.

Werner P, Voigt M, Keinanen K, Wisden W, Seeburg PH (1991) Cloning of a putative high-affinity kainate receptor expressed predominantly in hippocampal CA3 cells. Nature 351:742-744.

Wo ZG, Oswald RE (1994) Transmembrane topology of two kainate receptor subunits revealed by $N$-glycosylation. Proc Natl Acad Sci 91:7154-7158.

Woodgett JR, Gould KL, Hunter T (1986) Substrate specificity of protein kinase C: use of synthetic peptides corresponding to physiological sites as probes for substrate recognition requirements. Eur J Biochem 161:177-184.

Yamazaki M, Araki K, Shibata A, Mishina M (1992) Molecular cloning of a cDNA encoding a novel member of the mouse glutamate receptor channel family. Biochem Biophys Res Commun 183:886892. 